\title{
Er samkvæmni í árangri verðbréfasjóða?
}

\author{
Gylfi Magnússon, Haukur C. Benediktsson og Kári Sigurðsson. ${ }^{1}$
}

\begin{abstract}
Ágrip
Í pessari rannsókn er skoðað hvort samkvæmni sé yfir tíma í árangri við stjórnun íslenskra verðbréfasjóða. Byggt er á gögnum fyrir árin 1998 til 2005 yfir nær alla sjóði sem störfuðu á tímabilinu. Prenns konar aðferðum er beitt til að skoða hvort ávöxtun eitt ár hefur forspárgildi fyrir árið á eftir. Niðurstaða rannsóknarinnar er að fyrri árangur við stjórnun sjóðanna virðist ekki vera góð vísbending um framtíðarárangur. Pó sjást einhver merki um samkvæmni eða ósamkvæmi milli tímabila pegar einstakar tegundir verðbréfasjóða eru skoðaðar. Pannig er jákvætt samband á milli fyrri árangurs og framtíðarárangurs hjá sjóðum sem fjárfesta í erlendum hlutabréfum en neikvætt hjá innlendum hlutabréfasjóðum. Í báđum tilfellum er sambandið pó veikt og getur átt sér ýmsar skýringar.
\end{abstract}

\begin{abstract}
This study analyses the performance persistence of Icelandic mutual funds. The study uses data for almost all funds that were operated between 1998 and 2005. Three different methods are applied to analyze whether the performance in a given year can be used to predict performance in the following year. The conclusion is that prior performance is not a good indicator of subsequent performance. When individual types of mutual funds are analyzed there are though some examples of time consistency or inconsistency. There is thus a positive correlation between prior and subsequent returns for funds that invest in foreign stocks but a negative correlation for funds that invest in domestic stocks. In both cases the link is however weak and could have several explanations.
\end{abstract}

JEL flokkun: K2; L4

Lykilhugtök: Verðbréfasjóđir, samkvæmni i árangri; Mutual Funds, Performance Persistence

1 Gylfi Magnússon er dósent í viðskipta- og hagfræðideild Háskóla Íslands. Haukur C. Benediktsson er lektor í viðskipta- og hagfræðideild Háskóla Íslands. Kári Sigurðsson er lektor við Háskólann í Reykjavík. Höfundar pakka starfsfólki sjóðastýringarfyrirtækja fyrir að veita aðgang að gögnum fyrir rannsóknina. 


\section{Inngangur}

Verðbréfasjóðir hafa nú verið starfræktir á Íslandi í rúm 20 ár eða allt frá árinu 1985. Líkt og margir aðrir geirar fjármálamarkaðarins hefur pessi vaxið mjög ört, að jafnaði um nær 30\% á ári að raunvirði frá árslokum 1985. Í lok árs 2006 voru eignir sjóðanna um 450 milljarðar króna eða um 40\% af vergri landsframleiðslu. Mynd 1 sýnir árlegan vöxt sjóðanna að raunvirði frá árinu 1985.

Sjóðirnir eru mjög misjafnir og eignasamsetning peirra ólík. Pegar á heildina er litið er uppistaðan í eignum peirra innlend skuldabréf og líkar eignir, ýmist skuldabréf eða aðrar kröfur á innlendar fjármálastofnanir eða skuldabréf annarra fyrirtækja eða opinberra aðila. Tafla 1 sýnir sundurliðun á eignum sjóðanna í lok árs 2006.

Sjóðastýringarfyrirtæki auglýsa töluvert til að ná hylli fjárfesta. Auglýsingarnar vekja iðulega athygli á fortíðarávöxtun, hafi hún reynst góð. Jafnvel pótt oft sé tekið fram í smáa letrinu að fortíðarávöxtun sé ekki ávísun á framtíðarárangur gefa auglýsingarnar pað óneitanlega til kynna að fyrri árangur sé einhverskonar mælikvarði á gæði eða gefi fyrirheit um góðan árangur í framtíð.

Auglýsingar sjóðastýringarfyrirtækja hafa próast nokkuð undanfarna áratugi. Á síðasta áratug mátti gjarnan sjá auglýsingar um góða fortíðarávöxtun par sem sjóðir pess fyrirtækis sem auglýsti komu ávallt mjög vel út. Í upphafi pessa áratugs byrjaði Lánstraust að safna upplýsingum um ávöxtun sjóđa á kerfisbundinn hátt og skömmu síðar fóru sjóðastýringarfyrirtækin eingöngu að auglýsa ávöxtunartölur frá Lánstrausti. Par af leiðandi höfðu pau minna svigrúm til að ákveða ávöxtunartímabil. Á sama tíma var hægt að fá skattaafslátt vegna kaupa á hlutabréfum og ekki var óalgengt að sjá himinháar ávöxtunartölur par sem búið var að reikna skattaafsláttinn sem ávöxtun. Núna er hins vegar búið að leggja skattaafsláttinn niður og auglýsingar sjóðastýringarfyrirtækjanna komnar í betra jafnvægi.

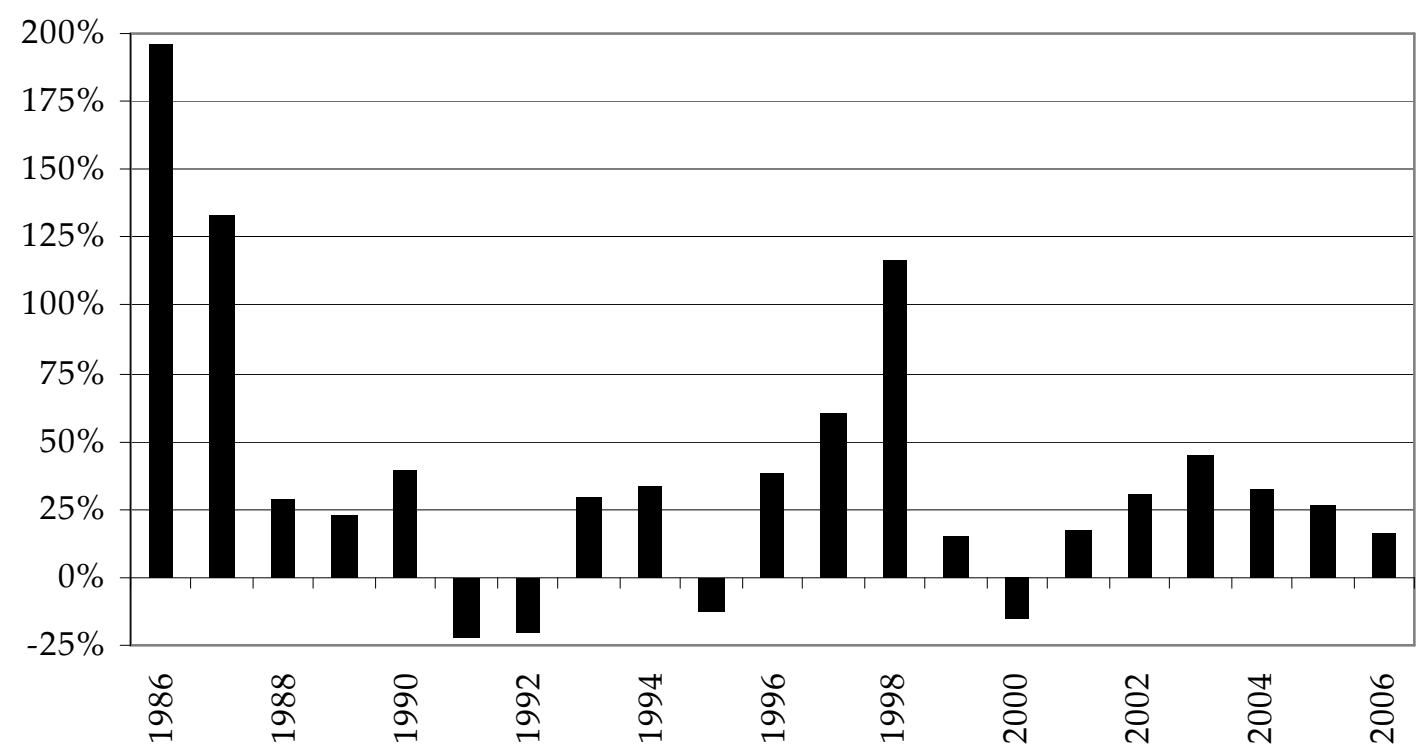

Mynd1. Vöxtur verðbréfasjóða að raunvirði 1986 til 2006 Heimild: Seðlabanki Íslands og útreikningar höfunda. 
Tafla 1. Eignir verðbréfasjóða í lok árs 2006.

\begin{tabular}{lrr}
\hline & M.kr. & Hlutfall \\
\hline Verðbréf fyrirtækja & 139.219 & $30,9 \%$ \\
Ríki, sveitarfélög og ÍLS & 108.935 & $24,2 \%$ \\
Verðbréf fjármálastofnana & 67.625 & $15,0 \%$ \\
Innlend hlutabréf & 47.837 & $10,6 \%$ \\
Innstæður og kröfur á lánastofnanir & 46.143 & $10,2 \%$ \\
Erlend hlutabréf & 13.207 & $2,9 \%$ \\
Erlend skuldabréf & 10.576 & $2,3 \%$ \\
Erlend hlutdeildarskírteini & 9.489 & $2,1 \%$ \\
Innlend hlutdeildarskírteini & 5.379 & $1,2 \%$ \\
Aðrar eignir & 2.011 & $0,4 \%$ \\
\hline \multicolumn{2}{c}{ Heimild: Seðlabanki Íslands og útreikningar höfunda. } \\
\hline
\end{tabular}

Vísbendingar eru um að góð fortíðarávöxtun dragi fé inn í sjóðina á Íslandi, líkt og algengast virðist erlendis, en að sjóðir sem skilað hafa lakri ávöxtun laði síður til sín fé (Kári Sigurðsson o.fl., 2006). Раð er merki pess að fjárfestar telji að fortíðarávöxtun gefi vísbendingu um framtíðarávöxtun, p.e. að vænlegra sé að veðja á sjóði sem skilað hafa góðri ávöxtun en pá sem skilað hafa lakari ávöxtun.

\section{Fyrri rannsóknir}

Til er fjöldi erlendra rannsókna á árangri við stjórnun sjóða og hafa margir skoðað hvort finna megi dæmi um sjóðstjóra sem ná kerfisbundið betri árangri en aðrir. Рað má heita sígilt viðfangsefni að reyna að greina á milli peirra sem eru einfaldlega heppnir nokkur ár í röð og peirra sem hafa í raun hæfileika til að gera betur en markaðurinn. Öðrum præði er hér verið að kanna skilvirkni markaða. Sýni markaðir meðalsterka skilvirkni (semi-strong efficiency) ætti ekki að vera svigrúm til að ná betri árangri með pví að velja bréf í sjóð en með hlutlausri eignastýringu, að teknu tilliti til áhættu. Líkt og Grossman og Stiglitz (1980) bentu á samrýmist slík skilvirkni pó ekki jafnvægi á markaðinum fyrir upplýsingar um verðmæti eigna. Í jafnvægi væri við pví að búast að verð endurspeglaði ekki einhvern lítinn hluta slíkra upplýsinga en að væntur kostnaður við að afla og nýta frekari upplýsingar væri jafnmikill og væntur ávinningur. Hafi Grossman og Stiglitz rétt fyrir sér er hugsanlegt að peir sem hafa meiri hæfileika en aðrir til að finna rangt verðlagðar eignir (e. security selection) eða til að sjá fyrir verðsveiflur á mörkuðum (e. market timing) geti náð betri árangri en fengist með hlutlausri eignastýringu, p.e. gert betur en markaðurinn.

Раð flækir síðan myndina að kostnaður við eignastýringu getur verið allnokkur og er alla jafna meiri við virka en hlutlausa stýringu. Peir sem beita virkri eignastýringu purfa að vinna upp pann mun eigi sjóðir peirra að skila meiru en sjóðir í hlutlausri stýringu. Ýmis tölfræðileg vandamál skjóta einnig upp kollinum við mat á árangri við sjóðstjórnun. Í mörgum tilfellum er erfitt að finna gögn um sjóði sem hafa hætt starfsemi og pví hefur hér verið stuðst við gagnasöfn með tölum um sjóði sem eru enn starfandi pegar rannsóknin er gerð. Slík söfn eru ekki dæmigerð fyrir alla sjóði par sem pau búa við seiglubjögun² (e.

2 Pórólfur Matthíasson átti hugmyndina að pessari pýðingu og eru honum færðar pakkir fyrir. Einnig hefur verið stungið upp á að pýða hugtakið sem brotthvarfsbjögun. 
survivorship bias). Sérstaklega er við pví að búast að í pau vanti tölur um sjóði sem hafa náð lélegum árangri enda eru peir líklegri en aðrir til að hætta rekstri.

Pá er oft erfitt að finna samanburðarhæfa sjóði eða að umreikna árangur sjóða til að gera hann samanburðarhæfan. Pannig er oft á tíðum erfitt að greina á milli áhættupóknunar og raunverulegs árangurs við að ná góðri ávöxtun án pess að auka áhættu.

Grein Jensen (1968) hafði lengi vel mikil áhrif á hugmyndir manna um árangur við sjóðstjórnun. Niðurstaða hans, eftir að hafa skoðað gögn frá 1945 til 1964, var að tilviljun ein réði pví hvaða sjóðir skiluðu bestum árangri hverju sinni. Pessi niðurstaða var í góðu samræmi við hugmyndir manna um skilvirkan markað. Seinni tíma rannsóknir hafa hins vegar í mörgum tilfellum leitt í ljós frávik sem illa samrýmast kenningum um skilvirka markaði.

Reyndar samræma Berk og Green (2004) hugmyndina um að sumir sjóðstjórar hafi hæfileika til að velja hlutabréf og skilvirkni markaða með pví að gera ráð fyrir stærðaróhagkvæmni í sjóðastýringu. Samkvæmt peirra hugmynd minnkar árangur sjóðstjóra eftir pví sem virði eigna í stýringu eykst. Fjárfestar gera sér grein fyrir pví að sjóðstjórar hafa mismunandi hæfileika og pyrpast par af leiðandi í pá sjóði sem skila góðum árangri. Við pað eykst virði eigna og árangur dvínar. Jafnvægi næst svo par sem enginn sjóðstjóri skilar ávöxtun umfram markaðinn.

Grinblatt og Titman (1992) skoðuðu 279 bandaríska sjóði frá 1974 til 1984. Ólíkt pví sem tíðkaðist í fyrri rannsóknum skoðuðu peir árangur fjárfestinga frekar en pá ávöxtun sem sjóðirnir skiluðu eigendum sínum, p.e. ekki var horft til kostnaðar við rekstur sjóðanna. Peir komust að peirri niðurstöðu að marktæk og jákvæð fylgni væri í ávöxtun sjóðanna yfir tíma og að hana væri ekki hægt að skýra með peim skýribreytum sem helst hefði verið bent á, svo sem mismunandi vali sjóðstjóranna á fyrirtækjum eftir stærð, arðgreiðslum, fyrri ávöxtun, CAPM betu eða mismiklu næmi sjóðanna fyrir páttum eins og vaxtabreytingum. Pótt höfundarnir gætu ekki slegið pví föstu hver skýringin á pessari fylgni væri töldu peir að vitneskja um hana hefði hagnýtt gildi fyrir fjárfesta, p.e. аð pað borgaði sig að kaupa í sjóðum sem náð hefðu góðum árangri í fortíð.

Goetzmann og Ibbotson (1994) skoðuðu ávöxtun 728 bandarískra sjóða frá 1976 til 1988. Líkt og Jensen (1968) horfðu peir sérstaklega til umframávöxtunar $(\alpha)$ skv. CAPM og notuðu ávöxtun S\&P-500 vísitölunnar sem mælikvarða á markaðinn. Peir komust að peirri niðurstöðu að marktæk fylgni væri í umframávöxtun yfir tíma og að hagkvæmt væri fyrir fjárfesta að setja fé sitt í sjóði sem skilað hefðu umframávöxtun árin á undan.

Elton, Gruber og Blake (1996) skoðuðu ávöxtun 188 bandarískra sjóđa á árunum 1977 til 1993. Niðurstöðurnar voru svipaðar og hjá Grinblatt og Titman. Elton og félagar fundu einnig jákvæða fylgni í ávöxtun yfir tíma. Slæman árangur peirra sjóða sem skiluðu fjárfestum minnstu virtist að mati peirra að stórum hluta mega rekja til mikils kostnaðar. Munur á rekstrarkostnaði dugði hins vegar ekki til að skýra fylgni í ávöxtun yfir tíma hjá öðrum sjóðum.

Til að rannsaka orsakir pess að sumir hlutabréfasjóðir virðast sýna kerfisbundið betri eða verri ávöxtun en markaðurinn notaði Carhart (1997) gagnasafn fyrir bandaríska sjóði frá árunum 1962 til 1993 sem var laust við seiglubjögun . Niðurstaða hans var að mismuninn væri ekki hægt að rekja til mismikilla hæfileika stjórnenda sjóðanna til að velja hlutabréf. Hægt væri að skýra nær öll frávik með annars vegar mismiklu vægi nokkurra áhættupátta í eignasöfnum og hins vegar með misháum viðskiptakostnaði. Áhættupættirnir sem Carhart notaði sem skýristærðir byggðu á fyrri rannsóknum Fama og French (1993) og Jegadeesh og 
Titman (1993). Einu frávikin sem Carhart taldi erfitt að skýra með pessum hætti var árangur sumra peirra sjóða sem gengu kerfisbundið mjög illa.

Carhart fann nokkra fylgni í ávöxtun á milli ára en taldi að hana mætti skýra með fylgni í skýristærðum á milli ára. Sumir sjóðanna áttu bréf sem skiluðu sérstaklega góðri ávöxtun a.m.k. tvö ár í röð og pað skilaði sér í jákvæðri fylgni á milli ára í ávöxtun sjóðanna. Jegadeesh og Titman (1993) höfðu áđur bent á fylgni á milli ára í ávöxtun einstakra hlutabréfa, nánar tiltekið fundu peir merki um eins árs sveiflu eða skriðpunga (one year momentum) í verðpróun bréfa. Komst Carhart að peirri niðurstöðu að hún dygði til að skýra fylgni í ávöxtun sjóða. Carhart taldi hins vegar ekkert benda til pess að einstakir sjóðstjórar hefðu sýnt fram á hæfni til að velja bréf sem skiluðu óvenju góðri ávöxtun tvö eða fleiri ár í röð.

Daniel og félagar (1997) gagnrýna nokkuð aðferðafræði fyrrnefndrar rannsóknar Grinblatt og Titman (1992) og pá sérstaklega fyrir pað að par hafi ekki verið fyllilega tekið tillit til áhrifa skriðpunga í ávöxtun einstakra bréfa. Peir finna pó einnig nokkur merki pess að einstakir sjóðstjórar hafi hæfileika til að finna vænlega fjárfestingarkosti, p.e. rangt verðlögð hlutabréf. Daniel og félagar telja hins vegar að ávinningurinn sé pað lítill, eða um 100 punktar á ári fyrir dæmigerðan sjóð, að hann dugi varla til að vega upp kostnaðinn af virkri eignastýringu. Petta telja peir merki pess að markaðir séu eins skilvirkir og hægt er að búast við í ljósi niðurstöðu Grossman og Stiglitz (1980).

Wermers (2000) sundurliðaði árangur sjóðstjóra niður í nokkra pætti. Hann skoðaði pannig sérstaklega annars vegar hæfni peirra til að finna vænlega fjárfestingarkosti og hins vegar kostnað við rekstur sjóðanna. Niðurstaða hans var að ýmsir sjóðstjórar hefðu hæfileika til að finna vænleg hlutabréf en pað nægði ekki til að vinna upp kostnað við rekstur sjóðanna og lága ávöxtun pess hluta sjóðanna sem ekki var bundinn í hlutabréfum. Wermers notaði tvö gagnasöfn sem bæði geymdu gögn fyrir alla bandaríska hlutabréfasjóði, annað yfir pá sem starfræktir voru á árunum 1975 til 1994 en hitt náði yfir tímabilið 1992 til 1997.

Wermers komst að pví að áður en tekið var tillit til kostnaðar skiluðu sjóðirnir um 130 punktum á ári umfram viðmið. Um helmingur pessa eða 60 punktar var vegna pess að sjóðirnir lágu með bréf sem höfðu nokkuð aðra eiginleika en markaðurinn allur (p.e. meiri áhersla á ört vaxandi fyrirtæki, smá fyrirtæki og fyrirtæki sem höfðu skilað góðri ávöxtun í fortíð (skriðpungi)). Afgangurinn, 70 punktar, var vegna hæfileika sjóðstjóranna til að velja rétt bréf innan hvers flokks. Prátt fyrir petta skiluðu sjóðirnir um 100 punktum lægri ávöxtun en viðmiðið. Skýringarnar voru annars vegar að um 70 punktar töpuðust vegna lágrar ávöxtunar annarra eigna en hlutabréfa og 160 punktar vegna viðskiptakostnaðar og annars rekstrarkostnaðar sjóðanna.

Fyrrnefndar rannsóknir hafa allar byggt á bandarískum gögnum. Minna er til af rannsóknum á sjóðum sem starfræktir eru utan Bandaríkjanna en pó eitthvað. Allen og félagar (2003) fjalla um 13 breskar og 9 ástralskar rannsóknir, auk fjölmargra bandarískra. Bresku og áströlsku rannsóknirnar virðast skila svipuðum niðurstöðum og pær bandarísku, pótt pví fari fjarri að peim beri öllum saman. Allen og félagar telja að góð fyrri ávöxtun sé fremur veik og óáreiðanleg vísbending um góðan árangur í framtíð. Sé eitthvert samband parna á milli nái pað til fremur skamms tíma, eins eða tveggja ára. Góður árangur í fortíð hafi sáralítið ef nokkurt forspárgildi til lengri tíma en pað. Hins vegar virðast vera sterkari vísbendingar um að peir sem skilað hafa slæmum árangri muni einnig gera pað í framtíð.

Enn er mikið birt af rannsóknum á árangri við sjóðstjórnun. Nýlegar rannsóknir virðast renna stoðum undir pað að einstakir sjóðstjórar hafi hæfileika til að velja bréf. Kosowski og félagar (2006) endurbæta nokkuð líkan Carhart (1997) og beita pví á gögn um 1.788 
bandaríska sjóði frá árunum 1975 til 2002. Niðurstaða peirra er að árangur peirra sem skila bestu og verstu ávöxtuninni verði ekki skýrður með eðlilegum skýristærðum eða sem tilviljun. Peir telja pví að bestu sjóðstjórarnir hljóti að hafa hæfileika til að finna bréf sem eru vænlegir fjárfestingarkostir.

Ekki hafa verið unnar margar rannsóknir á íslenskum verðbréfasjóðum og pví erfitt að vísa til fyrri rannsókna á sviðinu hérlendis. Pó eru til nokkrar rannsóknir sem skoða einkum aðra pætti sjóðanna en hér eru til umfjöllunar en hafa pó einhverja snertifleti við pessa rannsókn.

Birgir Hákon Hafstein (2007) skoðar árangur innlendra hlutabréfasjóða og ber sérstaklega saman sjóði sem beita virkri og hlutlausri eignastýringu. Meðal athyglisverðra niðurstaðna er að lítill munur virðist vera á kostnaði fjárfesta hérlendis vegna kaupa í sjóðum í virkri eignastýringu annars vegar og hlutlausri hins vegar. Раð forskot vegna kostnaðar sem sjóðir í hlutlausri eignastýringu hafa alla jafna erlendis virðist pví ekki til staðar hérlendis. Ekki virðist hins vegar afgerandi munur á ávöxtun fjárfesta eftir pessari flokkun sjóða en Birgir Hákon bendir á að væntanlega purfi gögn fyrir lengra tímabil en hann byggir á ( 5 ár) til að skera úr um pað. Birgir Hákon bendir hins vegar á að sjóðir í virkri stýringu virðist í langflestum tilfellum skila verri ávöxtun en pað viðmið sem peir nota, pótt yfirlýst stefna sé að skila betri árangri en viðmiðið. Arnar Jón Sigurgeirsson (2001) komst að sömu niðurstöðu við skoðun á árangri sex íslenskra hlutabréfasjóða fyrir tímabilið frá ársbyrjun 1997 til mars 2001. Sjóðirnir voru allir í virkri stýringu en einungis einn peirra náði betri árangri en viðmiðið. ${ }^{3}$

\section{Gögn}

Í rannsókn pessari er byggt á gögnum um ávöxtun íslenskra sjóða frá janúar 1998 til desember 2005. Gögnin ná yfir nær alla sjóði sem voru starfræktir á tímabilinu, einnig pá sem hættu starfsemi. Gögnin eru pví ekki með seiglubjögun. Sjóðunum er skipt í fimm flokka samkvæmt flokkunarkerfi Lánstrausts, ${ }^{4}$ í sjóði sem fjárfesta í íslenskum hlutabréfum, erlendum hlutabréfum, íslenska peningamarkaðssjóði og íslenska og erlenda skuldabréfa-

Tafla 2. Fjöldi sjóða í úrtaki

\begin{tabular}{cccccc}
\hline & $\begin{array}{c}\text { Íslensk } \\
\text { hlutabréf }\end{array}$ & $\begin{array}{c}\text { Alpjóðleg } \\
\text { hlutabréf }\end{array}$ & $\begin{array}{c}\text { Íslenskur } \\
\text { peningamarkaður }\end{array}$ & $\begin{array}{c}\text { Íslensk } \\
\text { skuldabréf }\end{array}$ & $\begin{array}{c}\text { Alpjóðleg } \\
\text { skuldabréf }\end{array}$ \\
\hline 1998 & 2 & 3 & 3 & 19 & 4 \\
1999 & 6 & 10 & 3 & 23 & 5 \\
2000 & 6 & 12 & 3 & 26 & 4 \\
2001 & 7 & 14 & 3 & 30 & 3 \\
2002 & 7 & 18 & 4 & 27 & 3 \\
2003 & 7 & 12 & 3 & 19 & 1 \\
2004 & 6 & 9 & 3 & 17 & 2 \\
2005 & 6 & 11 & 3 & 17 & 2 \\
\hline \multicolumn{5}{c}{}
\end{tabular}

3 Sjóðirnir voru allir reknir sem hlutafélög, til að hægt væri að nýta skattaafslátt vegna fjárfestingar í hlutafélögum við kaup á bréfum í peim. Peir voru pví jafnframt skattlagðir sem hlutafélög. Árangur peirra er pví ekki sambærilegur við árangur peirra verðbréfasjóða sem nú eru á íslenskum markaði, en peir eru ekki hlutafélög.

${ }^{4}$ Sjá http://sjodir.lt.is/ 
sjóði. Gögnin voru vandlega yfirfarin og mat lagt á trúverðugleika peirra.

Pegar um var að ræða sjóði sem fjárfesta eingöngu í erlendum verðbréfum og gera upp í erlendum gjaldmiðli var verð hvers hlutar umreiknað yfir í íslenskar krónur áður en ávöxtun sjóðsins var reiknuð. Рar með er gengishagnaður og gengistap tekið með inn í ávöxtun sjóðsins til að endurspegla raunverulega ávöxtun frá sjónarhóli íslensks fjárfestis.

\section{Aðferðafræði}

Prenns konar aðferðafræði var beitt í pessari rannsókn, venslatöflum, óstikuðum aðferðum (e. non-parametric) og pví að búa til verðbréfasöfn skv. tilteknum reglum og skoða ávöxtun peirra.

\subsection{Venslatöflur}

Venslatöflur (e. contingency table) voru notaðar til að skoða hvort árangur við sjóðstjórnun eitt ár hefði forspárgildi fyrir næsta ár. Sjóðir eru flokkaðir eftir pví hvort peir skiluðu ávöxtun fyrir ofan eða neðan miðgildi sambærilegra sjóða hvert ár. Niðurstöðurnar eru síðan settar upp í töflu með tveimur dálkum og tveimur röðum. Árangur fyrra árs ræður röð, pannig að peir sem voru með ávöxtun yfir miðgildi eru í efri röð. Peir teljast sigurvegarar $(S)$ pað ár, aðrir taparar (T). Árangur síðara árs ræður dálki, pannig að peir sem voru með ávöxtun yfir miðgildi pað ár eru í fyrri dálkinum (S), hinir í peim síðari (T). Ef líkurnar á pví að vera fyrir ofan miðgildi síðara árið fara ekkert eftir frammistöðu fyrra árið er vænt gildi fjölda sjóða í hverjum reitanna fjögurra einfaldlega fjórðungur peirra sjóða sem eru í rekstri í viðkomandi flokki pað ár. Рað er jafnframt $\mathrm{H}_{0}$ tilgátan. Prófað er hvort sú tilgáta standist með pví að reikna út:

$$
Q=\frac{\left[N_{S, S}-E\right]^{2}+\left[N_{S, T}-E\right]^{2}+\left[N_{T, S}-E\right]^{2}+\left[N_{T, T}-E\right]^{2}}{E}
$$

Hér táknar $N$ fjölda sjóða og $E$ væntan fjölda. Sé $\mathrm{H}_{0}$ rétt pá fylgir $Q$ kí-kvaðrat-dreifingu með einni frígráđu (DeGroot, 1986, bls. 337).

\section{2 Óstikaðar aðferðir}

Vel er pekkt að ávöxtun á fjármálamörkuðum fylgir almennt ekki normaldreifingu. Sérstaklega er algengt að halar á dreifingu ávöxtunar séu pykkari en í normaldreifingu. Petta gerir beitingu algengra tölfræðiprófa sem byggja á normaldreifingu, svo sem t-prófs, varhugaverða pegar gögn af fjármálamarkaði eru skoðuð. Hins vegar eru til ýmsar aðferðir sem ekki byggja á normaldreifingu, m.a. Mann-Whitney-Wilcoxon (MWW) prófið sem er óstikað. •að byggir á raðtölum og gerir ekki kröfu um tiltekna dreifingu gagna. Til að leggja mat á samkvæmni í árangri við sjóðstjórnun var próað afbrigði af MWW sem hægt er að beita á pversniðsgögn eins og pau sem hér var unnið með.

Líkt og í MWW prófinu var byggt á röð. Sjóðum innan hvers flokks var raðað eftir árangri á hverju ári og síðan lagðar saman raðtölur, annars vegar fyrir sjóði sem höfðu skilað ávöxtun undir miðgildi flokksins árið áður (taparar) og hins vegar fyrir pá sjóði sem höfðu skilað ávöxtun yfir miðgildi (sigurvegarar). Niðurstaðan fyrir hvorn hóp var síðan borin saman við væntigildi hefði árangur árið áður ekki áhrif á röð, p.e. ef taparar árið áður væru jafnlíklegir og sigurvegarar til að raða sér í sérhvert sæti (væntigildið er pví einfaldlega miðja 
raðarinnar, t.d. sæti 4 ef sjö sjóðir eru í viðkomandi flokki). Loks voru samanlögð frávik frá væntigildi fyrir sigurvegara dregin frá samanlögðum frávikum frá væntigildi fyrir tapara.

Prófstærðin, $M$, var pví:

$$
M_{f}=\sum_{\hat{A} r}\left\lfloor\sum_{\text {taparar }_{t-1}}\left(R_{t}^{f}-E\left(R_{t}^{f}\right)\right)-\sum_{\text {sigurvegarar }_{t-1}}\left(R_{t}^{f}-E\left(R_{t}^{f}\right)\right)\right\rfloor
$$

Par sem $R_{t}^{f}$ er raðtala og $E\left(R_{t}^{f}\right)$ er vænt raðtala sjóðs $f$ á ári $t$. Pað væri merki um samkvæmni í ávöxtun ef taparar röðuðu sér kerfisbundið í neðstu sætin og sigurvegar í pau efstu og væri $M$ pá neikvætt. Raði taparar sér hins vegar í efstu sætin en sigurvegarar frá fyrra ári í pau neðstu væri pað merki um ósamkvæmni og $M$ jákvætt. Ef hvorki væri um samkvæmni né ósamkvæmni að ræða ætti $M$ að vera nálægt núlli.

Til að sjá hvort frávikin væru tölfræðilega marktæk var búið til einfalt hermilíkan sem raðaði sjóðum af handahófi ár eftir ár. Hermilíkanið byggði á sama fjölda sjóða og voru í viðkomandi flokki og sama fjölda sigurvegara og tapara. Frávik frá væntri röð voru reiknuð með sama hætti í hermilíkaninu og pegar gögnin voru skoðuð. Hermilíkanið var keyrt 5.000 sinnum fyrir hvern flokk til að fá mat á líkindadreifingu fyrir $M$.

\subsection{Verðbréfasöfn}

Til að skoða hvort fjárfestar hefðu getað hagnast á pví að fjárfesta frekar í sigurvegurum en töpurum voru búin til tvenns konar verðbréfasöfn fyrir hvern flokk sjóða og hvert ár og meðalávöxtun peirra reiknuð. Í öðru verðbréfasafninu voru peir sjóðir sem talist höfðu sigurvegarar árið á undan en í hinu sjóðir sem töldust taparar árið áður. Sigurvegarar voru peir sjóðir sem skiluðu ávöxtun yfir miðgildi síðasta árs innan viðkomandi flokks. Vægi einstakra sjóða var jafnt innan viðkomandi verðbréfasafns. Söfnin voru síðan endurskoðuð árlega og ný söfn búin til. Samanburðurinn fólst í að bera saman meðalávöxtun pessara tveggja verðbréfasafna. $\mathrm{H}_{0}$ tilgátan í pessu tilfelli er að pau séu ekki frábrugðin hvort öðru.

Hlutabréfasjóðirnir voru jafnframt meðhöndlaðir aukalega. Ávöxtun hlutabréfasjóðasafnanna var leiðrétt sérstaklega fyrir áhættu samkvæmt CAPM jöfnunni og fjögurra pátta afbrigði af peirri jöfnu. Pá voru sigurvegarar og taparar innan hlutabréfaflokksins skilgreindir samkvæmt CAPM jöfnunni. Peir sjóðir sem skiluðu skurðpunkti skv. CAPM jöfnunni yfir miðgildi á tilteknu ári voru skilgreindir sem sigurvegarar pað ár, aðrir taparar:

$$
r_{i, t}-r_{f, t}=\alpha+\beta \cdot\left(r_{m, t}-r_{f, t}\right)+\varepsilon_{i, t}
$$

Par sem $r_{i, t}$ er ávöxtun viðkomandi sjóðs á tíma $t, r_{f, t}$ eru áhættulausir vextir, í pessu tilviki ávöxtun á vísitölu priggja mánaða ríkisvíxla. $\alpha$ er umframávöxtun, $\beta$ er beta-stuðull, p.e. samdreifni við ávöxtun markaðarins í hlutfalli við dreifni ávöxtunar markaðarins. Ávöxtun vísitölu aðallista í Kauphöll Íslands var notuð sem mælikvarði á ávöxtun markaðarins. $r_{m, t}$ er ávöxtun markaðarins og $\varepsilon$ afgangsliður. Allar ávöxtunartölur voru reiknaðar mánaðarlega og meðaltal peirra notað til að flokka í sigurvegara og tapara.

Einnig var stuðst við fjögurra pátta afbrigði af CAPM:

$$
r_{i t}-r_{t}^{r f}=\alpha+\beta^{m} \cdot\left(r_{t}^{m}-r_{t}^{r f}\right)+\beta^{S M B} \cdot S M B_{t}+\beta^{H M L} \cdot H M L_{t}+\beta^{U M D} \cdot U M D_{t}+\varepsilon_{i t}
$$

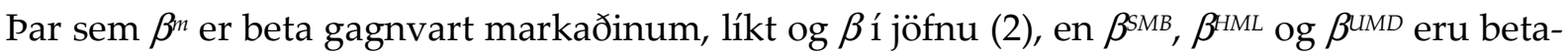
stuðlar gagnvart tilbúnum eignasöfnum, sbr. Fama og French (1993) og Carhart (1997). Pessi eignasöfn krefjast engrar fjárfestingar og hafa gnóttstöðu í smáum fyrirtækjum og skortstöðu í stórum (SMB), gnóttstöðu í fyrirtækjum með mikið bókfært eigið fé í hlutfalli við markaðsverð en skortstöðu í fyrirtækjum með lítið bókfært eigið fé (HML) og gnóttstöðu í 
fyrirtækjum með skriðpunga, p.e. peirra sem skiluðu hárri ávöxtun árið áður og skortstöðu í fyrirtækjum sem skiluðu lágri ávöxtun árið áður. Pessi tilbúnu eignasöfn fyrir Ísland byggja á vinnu Fuxén og félaga (2006).

\section{Niðurstöður}

\subsection{Venslatöflur}

Niðurstöður úr útreikningi á venslatöflum benda til pess að árangur fyrra árs sé vísbending um góðan árangur fyrir sjóði sem fjárfesta í alpjóðlegum hlutabréfum og íslenskum skuldabréfum. Veikt samband virðist einnig vera til staðar hjá íslenskum peningamarkaðssjóðum. Hins vegar virðist fyrri árangur ekki hafa spágildi fyrir árangur við sjóðstjórnun hjá sjóðum sem fjárfesta í alpjóðlegum skuldabréfum og íslenskum hlutabréfum. Pvert á móti virðist vera neikvætt samband milli árangurs á mismunandi tímabilum hjá íslenskum hlutabréfasjóðum ef árangur er mældur samkvæmt CAPM jöfnunni.

Skýring á pessari samkvæmni hjá sjóðum sem fjárfesta í íslenskum skuldabréfum gæti legið í pví að sjóðirnir fjárfesta í skuldabréfum til mislangs tíma. Nái vaxtahækkunar- eða lækkunarskeið oft til tveggja eða fleiri ára hefði pað pau áhrif að sömu sjóðirnir teldust sigurvegarar tvö ár í röð. Ef vextir eru t.d. á niðurleið tvö ár í röð yrðu sjóðir með löngum skuldabréfum sigurvegarar bæði árin en sjóðir sem kaupa einkum skuldabréf til skamms tíma kæmu verr út bæði árin, að öðru jöfnu. Рað er pví ekki ljóst af töflunni hvort um mismikla færni sjóðstjóra er að ræða. Vegna pess hve sjóðirnir eru fáir er erfitt að bregðast við pessu með pví að skipta pessum flokki verðbréfasjóða upp í undirflokka eftir pví hvers konar skuldabréf eru einkum keypt.

Svipuð skýring getur legið að baki samkvæmni í árangri alpjóðlegu hlutabréfasjóðanna. Pessir sjóðir fjárfesta á ólíkum mörkuðum og í ólíkum atvinnugreinum. Sé fylgni í ávöxtun á einstaka mörkuðum eða atvinnugreinum mun pað birtast sem samkvæmni í árangri sjóða í pessum flokki.

Pegar reiknuð er umframávöxtun $(\alpha)$ skv. CAPM kemur fram neikvæð fylgni yfir tíma í árangri íslenskra hlutabréfasjóða. Ekki liggur fyrir hver skýring pessa er. 
Tafla 3. Samkvæmni í árangri - venslatöflur

Á hverju ári eru sjóðir flokkaðir í „,sigurvegara” og „,tapara” eftir pví hvort ávöxtun er fyrir ofan eða neðan miðgildi á fyrra ári. Undantekning á pessu er síðasti hópurinn en par eru íslenskir hlutabréfasjóðir flokkaðir samkvæmt metnum skurðpunkti úr CAPM líkaninu á fyrra ári.

\begin{tabular}{llll}
\hline Íslensk hlutabréf & & \\
\hline \multirow{4}{*}{ Fyrra ár } & Síðara ár & \\
\cline { 3 - 3 } & Sigurvegari & 9 & Tapari \\
& Tapari & 12 & 11 \\
& p-gildi & 0,14 & 6
\end{tabular}

\begin{tabular}{|c|c|c|c|}
\hline \multicolumn{4}{|c|}{ Alpjóðleg hlutabréf } \\
\hline \multirow{5}{*}{ Fyrra ár } & \multirow{4}{*}{$\begin{array}{l}\text { Sigurvegari } \\
\text { Tapari }\end{array}$} & \multicolumn{2}{|l|}{ Síðara ár } \\
\hline & & $\overline{\text { Sigurvegari }}$ & Tapari \\
\hline & & 22 & 13 \\
\hline & & 11 & 21 \\
\hline & p-gildi & 0,02 & \\
\hline
\end{tabular}

\begin{tabular}{llll}
\hline Íslensk skuldabréf & & \\
\hline \multirow{4}{*}{ Fyrra ár } & Síđara ár & \\
\cline { 3 - 3 } & Sigurvegarvegari & Tapari \\
& Tapari & 46 & 33 \\
& p-gildi & 29 & 32 \\
& 0,03 & \\
\hline
\end{tabular}

\begin{tabular}{llll}
\hline \multicolumn{2}{l}{ Alpjóđleg skuldabréf } & & \\
\hline \multirow{4}{*}{ Fyrra ár } & Síðara ár & \\
\cline { 3 - 3 } & Sigurvegari & Tapari \\
& Tapari & 5 & 5 \\
& p-gildi & 0,41 & 3 \\
\end{tabular}

\begin{tabular}{llll}
\hline \multicolumn{3}{l}{ Íslenskur peningamarkaður } \\
\hline \multirow{4}{*}{ Fyrra ár } & Siguryara ár & \\
\cline { 3 - 4 } & Sigurvegari & Tapari \\
& Tapari & 7 & 6 \\
& p-gildi & 0,09 & 2 \\
\hline Íslensk hlutabréf, flokkun byggð á $\alpha$ skv. CAPM \\
\hline \multicolumn{3}{c}{ Síðara ár } \\
\cline { 3 - 4 } Fyrra ár & Sigurvegari & Tapari \\
& Tapari & 8 & 13 \\
& p-gildi & 0,01 & 4 \\
\hline
\end{tabular}




\section{2 Óstikaðar aðferðir}

Sjá má að tölfræðilega marktæk ósamkvæmni kom fram við skoðun á sjóðum sem fjárfestu í íslenskum hlutabréfum. Peir sem skiluðu árangri fyrir neðan miðgildi á tilteknu ári voru að meðaltali 0,61 sæti fyrir ofan miðgildi árið eftir. Peir sem talist höfðu sigurvegarar á fyrra ári lentu hins vegar að meðaltali 0,55 sætum fyrir neðan miðgildi. Niðurstaðan var einnig tölfræðilega marktæk fyrir sjóði sem fjárfestu í erlendum hlutabréfum. Par lentu taparar fyrra árs að meðaltali nær einu sæti fyrir neðan miðgildi en sigurvegarar fyrra árs einu sæti fyrir ofan miðgildi. Niðurstöður fyrir aðra flokka voru ekki tölfræðilega marktækar. Niðurstöðurnar eru pví í grófum dráttum svipaðar og í venslatöflunni.

\subsection{Verðbréfasöfn}

Pegar skoðuð er ávöxtun verðbréfasafnanna sem búin voru til ýmist úr peim sjóðum sem höfðu skilað ávöxtun yfir eða undir miðgildi árið áður kemur ekki í ljós tölfræðilega marktækur munur. Niðurstöðurnar eru pó í samræmi við fyrri niðurstöður. Mismunur á meðalávöxtun fyrir sigurvegara og tapara sem fjárfesta í alpjóðlegum hlutabréfum og íslenskum skuldabréfum er jákvæður en neikvæður fyrir íslenska hlutabréfasjóði.

Ef horft er á metna stuðla fyrir mismunandi áhættupætti kemur ekki í ljós kerfisbundinn munur á áhættu hjá sigurvegurum og töpurum.

Tafla 4. Samkvæmni í árangri - raðpróf

\begin{tabular}{|c|c|c|c|c|}
\hline \multirow[b]{2}{*}{ Flokkur } & \multicolumn{4}{|c|}{ Meðalfrávik } \\
\hline & Tapara & Sigurvegara & Niðurstaða & Líkur \\
\hline Íslensk hlutabréf & $-0,61$ & 0,55 & Ósamkvæmni & $3,2 \% *$ \\
\hline Alpjóðleg hlutabréf & 0,95 & $-1,01$ & Samkvæmni & $2,2 \% *$ \\
\hline Íslenskur peningamarkaður & 0,19 & 0,00 & Samkvæmni & $33,5 \%$ \\
\hline Íslensk skuldabréf & 0,39 & $-0,58$ & Samkvæmni & $19,8 \%$ \\
\hline Alpjóðleg skuldabréf & 0,00 & 0,10 & Ósamkvæmni & $45,4 \%$ \\
\hline
\end{tabular}

Tölfræðilegt marktæknistig er táknað sem: *=5\% marktektarkrafa. 
Tafla 5. Samkvæmni í árangri - verðbréfasöfn

\begin{tabular}{|c|c|c|c|c|c|c|c|c|c|c|c|c|c|}
\hline & \multirow{2}{*}{$\begin{array}{l}\text { Fjöldi } \\
\text { sjóða }\end{array}$} & \multirow{2}{*}{$\begin{array}{l}\text { Fjöldi } \\
\text { athugana }\end{array}$} & \multirow{2}{*}{$\begin{array}{l}\text { Meðal- } \\
\text { ávöxtun (\%) }\end{array}$} & \multicolumn{4}{|c|}{ CAPM } & \multicolumn{6}{|c|}{4 pátta líkan } \\
\hline & & & & $a(\%)$ & $\beta^{m}$ & $\mathrm{R}^{2}$ & $\operatorname{Std}(e)(\%)$ & $a(\%)$ & $\beta^{m}$ & $\beta^{S M B}$ & $\beta^{H M L}$ & ${ }^{L} \beta^{U M D}$ & $\mathrm{R}^{2} \quad \operatorname{Std}(e)(\%)$ \\
\hline \multicolumn{14}{|c|}{ Íslensk hlutabréf } \\
\hline Sigurvegarar & 8 & 84 & $\begin{array}{l}1,85 \\
(3,59)\end{array}$ & $\begin{array}{l}-0,03 \\
(0,13)\end{array}$ & $\begin{array}{l}0,89 \\
(20,33)\end{array}$ & 0,83 & 1,96 & $\begin{array}{l}-0,11 \\
(0,38)\end{array}$ & $\begin{array}{l}0,87 \\
(17,90)\end{array}$ & $\begin{array}{c}-0,03 \\
(0,77)\end{array}$ & $\begin{array}{l}-0,02 \\
(0,40)\end{array}$ & $\begin{array}{l}0,05 \\
(1,34)\end{array}$ & $0,841,93$ \\
\hline Taparar & 6 & 84 & $\begin{array}{l}2,21 \\
(4,23)\end{array}$ & $\begin{array}{l}0,33 \\
(1,39)\end{array}$ & $\begin{array}{l}0,89 \\
(18,87)\end{array}$ & 0,81 & 2,11 & $\begin{array}{l}0,22 \\
(0,75)\end{array}$ & $\begin{array}{l}0,88 \\
(16,63)\end{array}$ & $\begin{array}{c}-0,05 \\
(1,12)\end{array}$ & $\begin{array}{l}0,04 \\
(0,86)\end{array}$ & $\begin{array}{l}0,01 \\
(0,27)\end{array}$ & $0,822,09$ \\
\hline p-gildi mism. & & & 0,48 & 0,27 & 1,00 & & & 0,42 & 0,95 & 0,77 & 0,36 & 0,48 & \\
\hline \multicolumn{14}{|c|}{ Alpjóðleg hlutabréf } \\
\hline Sigurvegarar & 15 & 84 & $\begin{array}{l}0,27 \\
(0,05)\end{array}$ & & & & & & & & & & \\
\hline Taparar & 17 & 84 & $\begin{array}{l}0,05 \\
(0,01)\end{array}$ & & & & & & & & & & \\
\hline p-gildi mism. & & & 0,72 & & & & & & & & & & \\
\hline \multicolumn{14}{|c|}{ Íslensk skuldabréf } \\
\hline Sigurvegarar & 29 & 84 & $\begin{array}{l}0,69 \\
(0,89)\end{array}$ & & & & & & & & & & \\
\hline Taparar & 32 & 84 & $\begin{array}{l}0,61 \\
(0,91)\end{array}$ & & & & & & & & & & \\
\hline p-gildi mism. & & & 0,35 & & & & & & & & & & \\
\hline \multicolumn{14}{|c|}{ Alpjóðleg skuldabréf } \\
\hline Sigurvegarar & 4 & 72 & $\begin{array}{l}0,26 \\
(0,10)\end{array}$ & & & & & & & & & & \\
\hline Taparar & 5 & 72 & $\begin{array}{l}0,36 \\
(0,26)\end{array}$ & & & & & & & & & & \\
\hline p-gildi mism. & & & 0,74 & & & & & & & & & & \\
\hline
\end{tabular}


Tafla 5 (framhald)

\begin{tabular}{|c|c|c|c|c|c|c|c|c|c|c|c|}
\hline \multicolumn{12}{|c|}{ Íslenskur peningamarkaður } \\
\hline Sigurvegarar & 4 & 84 & $\begin{array}{l}0,69 \\
(3,89)\end{array}$ & & & & & & & & \\
\hline Taparar & 3 & 84 & $\begin{array}{l}0,68 \\
(4,25)\end{array}$ & & & & & & & & \\
\hline p-gildi mism. & & & 0,58 & & & & & & & & \\
\hline \multicolumn{12}{|c|}{ Íslensk hlutabréf, fl. skv. alfa } \\
\hline Sigurvegarar & 8 & 84 & $\begin{array}{l}1,84 \\
(0,38)\end{array}$ & $\begin{array}{l}-0,05 \\
(0,23)\end{array}$ & $\begin{array}{l}0,90 \quad 0,83 \\
(20,12)\end{array}$ & 2,00 & $\begin{array}{l}-0,14 \\
(0,51)\end{array}$ & $\begin{array}{lr}0,88 & -0,03 \\
(17,71) & (0,81\end{array}$ & $\begin{array}{l}-0,01 \\
(0,36)\end{array}$ & $\begin{array}{l}0,05 \\
(1,34)\end{array}$ & $0,841,97$ \\
\hline Taparar & 7 & 84 & $\begin{array}{l}2,22 \\
(0,47)\end{array}$ & $\begin{array}{l}0,35 \\
(1,47)\end{array}$ & $\begin{array}{l}0,89 \quad 0,81 \\
(18,59)\end{array}$ & 2,12 & $\begin{array}{l}0,26 \\
(0,87)\end{array}$ & $\begin{array}{ll}0,88 & -0,03 \\
(16,54) & (0,78\end{array}$ & $\begin{array}{l}0,04 \\
(0,98)\end{array}$ & $\begin{array}{l}-0,01 \\
(0,25)\end{array}$ & $0,812,11$ \\
\hline p-gildi mism. & & & 0,46 & 0,22 & 0,80 & & 0,33 & $0,98 \quad 0,99$ & 0,33 & 0,27 & \\
\hline
\end{tabular}

t-gildi á stikamati eru birt í svigum. Tölfræðilegt marktæknistig er táknað sem: ${ }^{* * *}=1 \%$ marktektarkrafa, ${ }^{* *}=5 \%$ marktektarkrafa og ${ }^{*}=10 \%$ marktektarkrafa. 


\section{Lokaorð}

Niðurstaða rannsóknarinnar er að fyrri árangur við stjórnun íslenskra verðbréfasjóða virðist almennt ekki vera góð vísbending um framtíðarárangur. Pegar einstakar tegundir verðbréfasjóða eru skoðaðar sjást pó einhver merki um samkvæmni á milli tímabila. Pannig er jákvætt samband á milli fyrri árangurs og framtíðarárangurs hjá sjóðum sem fjárfesta í erlendum hlutabréfum en neikvætt hjá innlendum hlutabréfasjóðum. Í báðum tilfellum er sambandið pó veikt og getur átt sér ýmsar skýringar.

Niðurstöðurnar fyrir íslenska markaðinn koma ekki á óvart í ljósi rannsókna á stærri og eldri mörkuðum. Erfitt hefur reynst að finna par traustar vísbendingar um samkvæmni í árangri yfir tíma. Hafi pær fundist eiga pær yfirleitt við lítinn hluta af mjög mörgum sjóðum. Раð hve fáir íslensku sjóðirnir eru dregur úr líkunum á pví að hægt sé að fá sömu niðurstöðu hér. Pá torveldar pað alla tölfræðivinnu að íslenski markaðurinn er ungur og sjóðirnir sem á honum starfa enn yngri. Tímaraðir eru pví enn stuttar. Með fjölgun sjóða og lengri líftíma peirra kann síðar meir að verða mögulegt að finna tölfræðilega marktæk frávik í ávöxtun sem varpa betra ljósi á eiginleika íslenska markaðarins, pótt pað sé illkleift nú.

\section{Heimildir}

Allen, D., T. Brailsford, R. Bird og R. Faff. (2003). A Review of the Research on the Past Performance of Managed Funds. Skýrsla unnin fyrir Australian Securities and Investment Commission.

Berk, J. B. og Green, R. C. (2004). Mutual fund flows and performance in rational markets. Journal of Political Economy 112, 1269-1295.

Arnar Jón Sigurgeirsson (2001). Frammistöđumat verðbréfasjóða. Lokaritgerð (B.S.) í viðskiptafræði frá Háskóla Íslands.

Birgir Hákon Hafstein (2007). Virk og hlutlaus eignastýring - Árangur innlendra hlutabréfasjóða. Lokaritgerð (B.S.) í hagfræði við Háskóla Íslands.

Brown, S. J. og Goetzmann, W. N. (1995). Performance Persistence. Journal of Finance, 50(2), 679-698.

Carhart, M. M. (1997). On Persistence in Mutual Fund Performance. Journal of Finance, 52, 5782.

Chen, J., Hong, H., Huang, M. og Kubik, J.D. (2004). Does Fund Size Erode Mutual Fund Performance? The Role of Liquidity and Organization. American Economic Review. 94 (5) 1276-1302.

Kent, D., Grinblatt, M., Titman, S. og Wermers, R. (1997). Measuring Mutual Fund Performance with Characteristic-Based Benchmarks. The Journal of Finance. 52 (3), 10351058.

DeGroot, M. H. (1986). Probability and Statistics. Addison Wesley (2. útg.).

Elton, E. J., Gruber, M. J. og Blake, C. R. (1996). The Persistence of Risk-Adjusted Mutual Fund Performance. Journal of Business, 69(2), 133-157. 
Fama, E. F. og French, K.R. (1993). Common risk factors in the returns on stocks and bonds. Journal of Financial Economics 33, 3-56.

Fuxén, S.M., Kristjánsdóttir, H. D., Ragnarsdóttir, I. og Vésteinsdóttir, V. (2006). Hönnun $S M B, H M L$ og UMD faktora fyrir islenska hlutabréfamarkaðinn. Verkefni í námskeiði um eignastýringu í Háskólanum í Reykjavík.

Goetzmann, W. N. og Ibbotson, R. G. (1994). Do Winners Repeat? Patterns in mutual fund return behaviour. Journal of Portfolio Management, 20 (2), 9-18.

Grinblatt, M. og Titman, S. (1992). The Persistence of Mutual Fund Performance. Journal of Finance, 47(5), 1977-1984.

Grossman, Sanford J. og Stiglitz, J. E. (1980). On the impossibility of informationally efficient markets. American Economic Review. 70, 393-408.

Hendricks, D., Patel, J. og Zeckhauser, R. (1993). Hot Hands in Mutual Funds: Short-Run Persistence of Relative Performance, 1974-1988. Journal of Finance, 48(1), 93-130.

Jegadeesh, N. og Titman, S. (1993). Returns to Buying Winners and Selling Losers: Implications for Stock Market Efficiency. The Journal of Finance, 48 (1), 65-91.

Jensen, M. (1968). The Performance of Mutual Funds in the Period 1945-1964. Journal of Finance. (2) 389-416.

Kári Sigurðsson, Sara Margareta Fuxen og Valgerður Vésteinsdóttir (2006). Hvert er aðal málið við val á verðbréfasjóđi. Háskólinn í Reykjavík, óbirt handrit.

Kosowski, R., Timmerman, A., Wermers, R. og White, H. (2006). Can Mutual Fund "Stars" Really Pick Stocks? New Evidence from a Bootstrap Analysis. The Journal of Finance. 61 (6) 2551-2595.

Wermers, R. (2000). Mutual Fund Performance: An Empirical Decomposition into StockPicking Talent, Style, Transaction Costs, and Expenses. The Journal of Finance. 55 (4), 1655-1695. 


\section{Viðauki}

Tafla V.1. Sjóðir sem notaðir voru við rannsóknina, flokkaðir eftir fjárfestingastefnum

\begin{tabular}{|c|c|c|c|c|c|c|c|c|c|}
\hline Íslensk hlutabréf & & 1998 & 1999 & 2000 & 2001 & 2002 & 2003 & 2004 & 2005 \\
\hline ÍS-15 & BÍ & & $x$ & $x$ & $x$ & $x$ & $x$ & $x$ & $x$ \\
\hline Sjóður 10 & ISB & & $x$ & $x$ & $x$ & $x$ & $x$ & $x$ & $x$ \\
\hline Sjóður 6 & ISB & $x$ & $x$ & $x$ & $x$ & $x$ & $x$ & $x$ & $x$ \\
\hline Einingabréf 9 & KAUP & & $x$ & $x$ & $x$ & $x$ & $x$ & $x$ & $x$ \\
\hline Íslensk hlutabréf & KAUP & & & & $x$ & $\mathrm{x}$ & $x$ & & \\
\hline KB Úrvalsvísitölusjóður & KAUP & & & & & $x$ & $x$ & $x$ & $x$ \\
\hline LUX-Icelandic Equity Class & KAUP & $x$ & $x$ & $x$ & $x$ & & & & \\
\hline Úrvalsbréf & LAIS & & $\mathrm{x}$ & $x$ & $x$ & $x$ & $x$ & $x$ & $x$ \\
\hline Alpjóðleg hlutabréf & & 1998 & 1999 & 2000 & 2001 & 2002 & 2003 & 2004 & 2005 \\
\hline Alpjóða hlutabréfasjóðurinn & BÍ & & $\mathrm{x}$ & $\mathrm{x}$ & $x$ & $\mathrm{x}$ & & & \\
\hline Framsækni alpjóða hlutabréfasj. & BÍ & & $x$ & $x$ & $x$ & $x$ & & & \\
\hline Nýtæknisjóðurinn & BÍ & & & & $x$ & $x$ & & & \\
\hline Fjármál & ISB & & & & & $x$ & $x$ & & \\
\hline Heilsa & ISB & & & & & $x$ & $x$ & & \\
\hline ISB Global Equity & ISB & & & & & & & & $\mathrm{x}$ \\
\hline Lífstíll & ISB & & & & & $x$ & $x$ & & \\
\hline Sjóður 12 & ISB & & & $x$ & $x$ & $x$ & $x$ & $x$ & $x$ \\
\hline Tækni & ISB & & & & & $x$ & $x$ & & \\
\hline Einingabréf 6 & KAUP & $x$ & $x$ & $x$ & $x$ & $x$ & & & \\
\hline Kaupth. SICAV Tech \& Health & KAUP & & $x$ & $x$ & $x$ & $x$ & & & \\
\hline Kaupthing SICAV America & KAUP & & $x$ & $x$ & $x$ & $x$ & $x$ & $x$ & $x$ \\
\hline Kaupthing SICAV Asia & KAUP & & $x$ & $\mathrm{x}$ & $x$ & $x$ & $x$ & $x$ & $x$ \\
\hline Kaupthing SICAV Europe & KAUP & & $x$ & $x$ & $x$ & $x$ & $x$ & $x$ & $x$ \\
\hline Kaupthing SICAV Intl Equity & KAUP & $x$ & $x$ & $x$ & $x$ & $x$ & $x$ & $x$ & $x$ \\
\hline Kaupthing SICAV New Opport. & KAUP & & $x$ & $x$ & $x$ & $x$ & $x$ & $x$ & $x$ \\
\hline LUX - Global growth class & KAUP & & & & & & $x$ & $x$ & $x$ \\
\hline LUX-Global Equity Class & KAUP & $x$ & $x$ & $x$ & $x$ & $x$ & & & \\
\hline LUX-Global Technology Class & KAUP & & & $x$ & $x$ & $x$ & & & \\
\hline LUX-Global Value Class & KAUP & & & & & & & $x$ & $x$ \\
\hline Nordic Growth Class & KAUP & & & & $x$ & $x$ & $x$ & $x$ & $x$ \\
\hline Global Equity Fund & LAIS & & & & & & & & $\mathrm{x}$ \\
\hline Peningamarkaðssjóðir & & 1998 & 1999 & 2000 & 2001 & 2002 & 2003 & 2004 & 2005 \\
\hline Sjóður 9 & ISB & $x$ & $\mathrm{x}$ & $\mathrm{x}$ & $\mathrm{x}$ & $x$ & $x$ & $\mathrm{x}$ & $x$ \\
\hline Einingabréf 7, Peningamarkaðssj. & KAUP & $x$ & $x$ & $x$ & $x$ & $x$ & & & \\
\hline KB Peningamarkaðssjóður & KAUP & & & & & $x$ & $x$ & $x$ & $x$ \\
\hline Peningabréf & LAIS & $x$ & $x$ & $\mathrm{x}$ & $x$ & $x$ & $x$ & $x$ & $x$ \\
\hline
\end{tabular}


Tafla V.1 (framhald)

\begin{tabular}{|c|c|c|c|c|c|c|c|c|c|}
\hline Íslensk skuldabréf & & 1998 & 1999 & 2000 & 2001 & 2002 & 2003 & 2004 & 2005 \\
\hline Eignarskattsfrjáls sjóður BÍ & BÍ & $x$ & $x$ & $\mathrm{x}$ & $x$ & $x$ & $x$ & & \\
\hline Hávaxtabréf & BÍ & & & & $\mathrm{x}$ & $\mathrm{x}$ & & & \\
\hline Langtímasjóður BÍ & BÍ & $\mathrm{x}$ & $\mathrm{x}$ & $\mathrm{x}$ & $\mathrm{x}$ & $\mathrm{x}$ & $\mathrm{x}$ & & \\
\hline Peningamarkaðsbréf & BÍ & & & & & & $x$ & & \\
\hline Veltubréf & BÍ & $x$ & $x$ & $x$ & $x$ & $x$ & & & \\
\hline Sjóður 1 & ISB & $x$ & $x$ & $x$ & $x$ & $x$ & $x$ & $x$ & $\mathrm{x}$ \\
\hline Sjóður 11 & ISB & & $x$ & $x$ & $x$ & $x$ & $x$ & $x$ & $x$ \\
\hline Sjóður 2 & ISB & $\mathrm{x}$ & $x$ & & & & & & \\
\hline Sjóður 5 & ISB & $\mathrm{x}$ & $\mathrm{x}$ & $\mathrm{x}$ & $\mathrm{x}$ & $\mathrm{x}$ & $\mathrm{x}$ & $\mathrm{x}$ & $\mathrm{x}$ \\
\hline Sjóður 7 & ISB & $\mathrm{x}$ & $x$ & $x$ & $x$ & $x$ & $x$ & $x$ & $\mathrm{x}$ \\
\hline Sjóður 8 & ISB & $\mathrm{x}$ & $x$ & $x$ & $x$ & $x$ & & & \\
\hline Einingabréf 11 & KAUP & & & $\mathrm{x}$ & $\mathrm{x}$ & $\mathrm{x}$ & $\mathrm{x}$ & & \\
\hline Einingabréf 2 & KAUP & $\mathrm{x}$ & $\mathrm{x}$ & $\mathrm{x}$ & $\mathrm{x}$ & $\mathrm{x}$ & & & \\
\hline Einingabréf 8 & KAUP & $\mathrm{x}$ & $x$ & $x$ & $x$ & $x$ & & & \\
\hline Fyrirtækjadeild & KAUP & & & & $x$ & & & & \\
\hline Húsbréfadeild & KAUP & & & $x$ & $x$ & $x$ & & & \\
\hline Íslensk skuldabréf, skammt. & KAUP & & & & $x$ & $x$ & $x$ & & \\
\hline KB Hávaxtasjóður & KAUP & & & & & & & $\mathrm{x}$ & $\mathrm{x}$ \\
\hline KB Ríkisverðbréfasj.-millilangur & KAUP & & & & & & & $x$ & $x$ \\
\hline KB Ríkisverðbréfasjóður-langur & KAUP & & & & & & & $x$ & $\mathrm{x}$ \\
\hline KB Skammtímasjóður & KAUP & & & & & & & $x$ & $\mathrm{x}$ \\
\hline LUX-Icelandic Bond Class & KAUP & $x$ & $x$ & $x$ & $x$ & & & & \\
\hline Skammtímabréf & KAUP & $\mathrm{x}$ & $\mathrm{x}$ & $\mathrm{x}$ & $\mathrm{x}$ & $\mathrm{x}$ & & & \\
\hline Skyndibréf & KAUP & $\mathrm{x}$ & $x$ & $x$ & $x$ & $x$ & & & \\
\hline Spariskírteinadeild & KAUP & & & $x$ & $x$ & $x$ & $x$ & & \\
\hline Tekjubréf & KAUP & $\mathrm{x}$ & $\mathrm{x}$ & $\mathrm{x}$ & $x$ & $x$ & & & \\
\hline Fyrirtækjabréf & LAIS & $x$ & $x$ & $x$ & $x$ & $x$ & $x$ & $x$ & $\mathrm{x}$ \\
\hline Launabréfadeild & LAIS & & $x$ & & & & & & \\
\hline Markaðsbréf 1 & LAIS & & $x$ & $x$ & $x$ & $x$ & $x$ & $x$ & $x$ \\
\hline Markaðsbréf 2 & LAIS & & $x$ & $x$ & $x$ & $x$ & $x$ & $x$ & $x$ \\
\hline Markaðsbréf 3 & LAIS & & $\mathrm{x}$ & $\mathrm{x}$ & $x$ & $\mathrm{x}$ & $\mathrm{x}$ & $\mathrm{x}$ & $\mathrm{x}$ \\
\hline Markaðsbréf 4 & LAIS & & $x$ & $x$ & $x$ & $x$ & $x$ & $x$ & $\mathrm{x}$ \\
\hline Reiðubréfadeild & LAIS & $\mathrm{x}$ & $\mathrm{x}$ & $x$ & $x$ & $x$ & $x$ & $x$ & $\mathrm{x}$ \\
\hline Skuldabréfasjóður & LAIS & $\mathrm{x}$ & $x$ & $x$ & $x$ & $x$ & $x$ & $x$ & $x$ \\
\hline Sparibréf & LAIS & & & & & $x$ & $x$ & $x$ & $x$ \\
\hline Sýslubréfadeild & LAIS & $x$ & $x$ & $x$ & $x$ & & & & \\
\hline Pingbréfadeild & LAIS & $x$ & $x$ & $x$ & $x$ & & & & \\
\hline Áskriftarsjóður ríkisbréfa & SPRON & & & & $x$ & $x$ & $x$ & $x$ & $\mathrm{x}$ \\
\hline Alpjóðleg skuldabréf & & 1998 & 1999 & 2000 & 2001 & 2002 & 2003 & 2004 & 2005 \\
\hline Alpjóðleg skuldabréf & BÍ & & $x$ & $\mathrm{x}$ & & & & & \\
\hline Einingabréf 5 & KAUP & $\mathrm{x}$ & $x$ & & & & & & \\
\hline Einingabréf 10 & KAUP & $x$ & $x$ & $x$ & $x$ & $x$ & & & \\
\hline Kaupthing SICAV Intl. Bond & KAUP & $\mathrm{x}$ & $x$ & $x$ & $x$ & $x$ & & & \\
\hline LUX-Euro Bond Class & KAUP & $\mathrm{x}$ & $x$ & $x$ & $x$ & $x$ & $x$ & $x$ & $x$ \\
\hline LUX-US Bond Class & KAUP & & & & & & $x$ & $x$ & $\mathrm{x}$ \\
\hline
\end{tabular}


114 Tímarit um viðskipti og efnahagsmál 